\title{
Efficacy of an infectious hematopoietic necrosis (IHN) virus DNA vaccine in Chinook Oncorhynchus tshawytscha and sockeye O. nerka salmon
}

\author{
Kyle A. Garver ${ }^{1,2, *}$, Scott E. LaPatra ${ }^{3}$, Gael Kurath ${ }^{1,2}$ \\ ${ }^{1}$ Department of Pathobiology, University of Washington, Seattle, Washington 98195, USA \\ ${ }^{2}$ Western Fisheries Research Center, United States Geological Survey, Biological Resources Division, 6505 NE 65th St, \\ Seattle, Washington 98115, USA \\ ${ }^{3}$ Clear Springs Foods, Inc., Research Division, PO Box 712, Buhl, Idaho 83316, USA
}

\begin{abstract}
The level of protective immunity was determined for Chinook Oncorhynchus tshawytscha and sockeye/kokanee salmon (anadromous and landlocked) $O$. nerka following intramuscular vaccination with a DNA vaccine against the aquatic rhabdovirus, infectious hematopoietic necrosis virus (IHNV). A DNA vaccine containing the glycoprotein gene of IHNV protected Chinook and sockeye/kokanee salmon against waterborne or injection challenge with IHNV, and relative percent survival (RPS) values of 23 to $86 \%$ were obtained under a variety of lethal challenge conditions. Although this is significant protection, it is less than RPS values obtained in previous studies with rainbow trout $(O$. mykiss). In addition to the variability in the severity of the challenge and inherent host susceptibility differences, it appears that use of a cross-genogroup challenge virus strain may lead to reduced efficacy of the DNA vaccine. Neutralizing antibody titers were detected in both Chinook and sockeye that had been vaccinated with 1.0 and $0.1 \mu \mathrm{g}$ doses of the DNA vaccine, and vaccinated fish responded to viral challenges with higher antibody titers than mock-vaccinated control fish.
\end{abstract}

KEY WORDS: DNA vaccine - Infectious hematopoietic necrosis virus · IHNV · Chinook salmon · Sockeye salmon · Cross-genogroup and intragenogroup challenge

\section{INTRODUCTION}

Infectious hematopoietic necrosis virus (IHNV) is an aquatic rhabdovirus that causes significant mortality in salmon and trout. The disease was first reported in cultured sockeye salmon Oncorhynchus nerka in the Pacific Northwest of North America (Rucker et al. 1953, Watson et al. 1954) and has since affected stocks of kokanee (landlocked) O. nerka, Chinook salmon $O$. tshawytscha, steelhead (anadromous) O. mykiss, rainbow trout $O$. mykiss and Atlantic salmon Salmo salar (Ross et al. 1960, Amend et al. 1969, Mulcahy \& Wood 1986). The virus causes an acute, systemic disease and depending upon fish species, virus strain, and environ- mental conditions, losses of greater than $90 \%$ may result (LaPatra 1998). Within Alaska, the average annual IHNV prevalence for female spawning sockeye salmon from 1981 to 2000 was $40.4 \%$ and the estimated total revenues lost from juvenile mortality due to IHNV were $\$ 8.6$ million in 1992 (Meyers et al. 2003). In California, IHNV was first reported in Chinook salmon in 1960 (Ross et al. 1960, Wingfield \& Chan 1970) and has since been associated with the loss of up to 6 million young Chinook salmon $(50 \%$ of production) at Feather River Hatchery in 2000 (W. Cox pers. comm.). IHNV also hinders propagation programs for threatened and endangered salmon stocks. In 1995, IHNV caused an epidemic in an Endangered Species 
Act (ESA)-listed spring Chinook stock at Lookingglass hatchery in Oregon (Groberg 1999), and in 2002 IHN disease in endangered Redfish Lake sockeye resulted in the destruction of 68000 pre-smolts (Anonymous 2002).

The catastrophic losses suffered by both aquaculture and resource mitigation facilities due to IHN disease have led to many efforts to develop vaccines against this viral agent. One candidate vaccine type that has proven highly protective is a DNA-based vaccine (Anderson et al. 1996, Corbeil et al. 1999). A DNA vaccine encoding the glycoprotein $(\mathrm{G})$ gene of the IHNV strain RB1 was shown to be highly efficacious, first in rainbow trout (Anderson et al. 1996) and later in Atlantic salmon (Traxler et al. 1999). Since then, studies investigating a similar IHNV DNA vaccine (denoted pIHNw-G) that encodes the G-gene from the IHNV WRAC strain, revealed high efficacy when administered intramuscularly as a single low dose in rainbow trout (Corbeil et al. 2000b, LaPatra et al. 2000). Additionally, the vaccine provided broad protection against a wide diversity of IHNV strains (Corbeil et al. 2000b) and proved to be efficacious as soon as $4 \mathrm{~d}$ after vaccination (LaPatra et al. 2001).

Taken together, the above experiments document reproducibly high efficacy and illustrate the many positive features of IHNV DNA vaccines; yet the breadth of protection in species other than rainbow trout and Atlantic salmon has not been demonstrated. The ability of a DNA vaccine to protect multiple salmonid species against IHN disease is important for its future use as a method for control of IHNV. Therefore, for this report we evaluated the efficacy of the pIHNw-G DNA vaccine in Chinook, sockeye, kokanee salmon and rainbow trout. Due to differences in the susceptibility of these fish species to certain strains of IHNV (LaPatra et al. 1990a,b, 1993a), the viral challenge models for each host species used different IHNV strains and were done by injection or waterborne exposure to achieve sufficiently high mortality for assessing vaccine efficacy. Vaccine efficacy was subsequently evaluated by measuring the survival of vaccinated fry and by determining neutralizing antibody titers.

\section{MATERIALS AND METHODS}

DNA plasmid constructs. The plasmids used in this study have been previously described (Corbeil et al. $2000 a, b)$. The vaccine plasmid pIHNw-G contains the gene for the G gene of the IHNV WRAC strain ATCC \#VR-1392 (LaPatra et al. 1994, Morzunov et al. 1995) placed downstream of the immediate-early enhancerpromoter sequences of the human cytomegalovirus (CMV). Similarly, the pLuc control plasmid contains the luciferase gene downstream of the CMV promoter sequence. Both plasmids were amplified in Escherichia coli strain DH5 $\alpha$ and plasmid DNA was purified by the alkaline lysis protocol of SaporitoIrwin et al. (1997).

Challenge viruses and propagation. Virus challenges of Chinook fry were done using the FR0031 isolate of IHNV (provided by R. P. Hedrick, University of California, Davis, CA), which originated from a clinical outbreak of IHN in Chinook salmon fry in 2000 at the Feather River hatchery in California. Virus challenges of sockeye and kokanee salmon fry were done with IHNV isolate BLk-94 (provided by J. Thomas, Washington Dept. of Fish and Wildlife, Olympia, WA), which originated from an asymptomatic adult sockeye salmon from Baker Lake, WA, in 1994 and consistently caused high mortality in pilot challenge studies with sockeye and kokanee salmon (K. A. Garver \& G. Kurath unpubl. data). Virus challenges of rainbow trout fry were done using IHNV isolate 220-90 obtained from a rainbow trout at Clear Springs Foods in 1990 (LaPatra et al. 1991). The use of different challenge virus strains for each host species was necessary because sufficient mortality was not achieved using virus strain 220-90 in pilot challenge studies of Chinook, sockeye and kokanee or using virus strains BLK94 and FR0031 in pilot challenge studies of rainbow trout (K. A. Garver \& G. Kurath unpubl. data). The challenge viruses were propagated and quantified using the EPC (Fijan et al. 1983) cell line as described previously (LaPatra et al. 1989).

Fish. Spring Chinook salmon fry (provided by R. Brunson, US Fish and Wildlife Service) from Entiat National Fish Hatchery, WA, and sockeye and kokanee salmon fry (provided by J. Varney and D. Huddle, Washington Dept. of Fish and Wildlife) from Baker Lake and Lake Whatcom, WA, respectively, were moved to the Western Fisheries Research Center, Seattle, WA, and held in $10^{\circ} \mathrm{C}$ pathogen-free water. Specific-pathogen-free rainbow trout fry from Clear Springs Foods were held at $15^{\circ} \mathrm{C}$ for 1 mo and then acclimated to $10^{\circ} \mathrm{C}$ prior to challenge. Fish were fed daily, at $1.5 \%$ of their body weight, a semi-moist pelleted diet (Bioproducts).

Vaccination. Chinook (average weight, $3.0 \mathrm{~g}$ ), sockeye (average weight, $0.7 \mathrm{~g}$ and $3.0 \mathrm{~g}$ ), kokanee salmon (average weight $1.7 \mathrm{~g}$ ), and rainbow trout (average weight $3.2 \mathrm{~g}$ ) were anesthetized by immersion in $100 \mu \mathrm{g} \mathrm{ml}^{-1}$ of tricaine methane sulfonate (MS-222; Argent Chemical Laboratory) and injected intramuscularly with the specified DNA vaccine dose (Table 1) in 25 or $50 \mu \mathrm{l}$ of TE $(10 \mathrm{mM}$ Tris-Cl, $1 \mathrm{mM}$ EDTA $\mathrm{pH}$ 8.0) into the left epaxial muscle below the dorsal fin with a 27G3/4" needle. Each treatment group was placed in separate $32 \mathrm{l}$ aquaria and held at $10^{\circ} \mathrm{C}$. 
Table 1. Oncorhynchus spp. infectious hematopoietic necrosis virus (IHNV) challenge experiment conditions. dpv: days post-vaccination; i.p.: intraperitoneal injection; imm.: waterborne immersion

\begin{tabular}{|c|c|c|c|c|c|c|c|}
\hline $\begin{array}{l}\text { Vaccine } \\
\text { trial }\end{array}$ & $\begin{array}{l}\text { Host species/ } \\
\text { size }(\mathrm{g})\end{array}$ & $\begin{array}{l}\text { No. of fish } \\
\text { per group }\end{array}$ & $\begin{array}{l}\text { pIHNw-G } \\
\text { doses }(\mu \mathrm{g})\end{array}$ & $\begin{array}{l}\text { Challenge } \\
\text { time (dpv) }\end{array}$ & $\begin{array}{l}\text { Challenge strain } \\
\text { (genogroup) }\end{array}$ & $\begin{array}{l}\text { Challenge route } \\
\text { and dose } \mathrm{e}^{\mathrm{b}}\end{array}$ & $\begin{array}{l}\text { Bled for } \\
\mathrm{NAb}^{\mathrm{c}}\end{array}$ \\
\hline $1 \mathrm{C}$ & Chinook/3.0 & $21-26$ & $0.1,1.0$ & 45 & FR0031 (L) & i.p., $3.6 \times 10^{7}$ & + \\
\hline $2 \mathrm{~S}$ & Sockeye/3.0 & 25 & $0.1,1.0$ & 35 & BLk-94 (U) & i.p., $1.7 \times 10^{7}$ & + \\
\hline $3 \mathrm{~S}$ & Sockeye/0.7 & 15 & $0.1,1.0$ & 28 & BLk-94 (U) & imm., $2 \times 10^{5}$ & - \\
\hline $4 \mathrm{~K}$ & Kokanee/1.7 & 25 & $0.1,1.0$ & 28 & BLk-94 (U) & imm., $2 \times 10^{5}$ & - \\
\hline $5 \mathrm{R}$ & Rainbow/3.2 & 20 & $0.1,1.0$ & 28 & $220-90(\mathrm{M})$ & imm., $1.2 \times 10^{5}$ & - \\
\hline
\end{tabular}

IHNV challenge of vaccinated fish. Table 1 summarizes the experimental conditions of 5 different vaccine trials conducted in this study. These conditions were chosen based on a series of pilot challenges that identified the virus strain, dose, and route of administration yielding the highest mortality for each fish species (K. A. Garver \& G. Kurath unpubl. data). Challenge virus doses used in the vaccine trials (Table 1) were much higher than the level that fish encounter naturally (Mulcahy et al. 1983). Chinook and sockeye salmon challenged by intraperitoneal (i.p.) injection (vaccine trial $1 \mathrm{C}$ and $2 \mathrm{~S}$ ) received 50 and $200 \mu \mathrm{l}$ of virus, respectively. For waterborne immersion challenge of sockeye, kokanee, and rainbow trout (vaccine trials $3 \mathrm{~S}, 4 \mathrm{~K}$, and 5R), fry were transferred to 51 aquaria containing 11 of water with the specified strain and dose of IHNV (Table 1). Fish were statically exposed to the challenge virus solution for $60 \mathrm{~min}$ at $10^{\circ} \mathrm{C}$. Water circulation was then resumed, allowing each aquarium to fill to its maximum capacity of $5 \mathrm{l}$. For all 5 vaccine trials, individuals from each treatment group were mock challenged either by i.p. injection of virus-free medium (trial 1C and $2 \mathrm{~S}$ ) or by the addition of virus-free medium into the water (trial $3 \mathrm{~S}, 4 \mathrm{~K}$, and $5 \mathrm{R}$ ).

According to the IHNV genetic typing system defined by Kurath et al. (2003), which is based on partial nucleotide sequence of the $G$ gene, virus strain FR0031 is in the L genogroup, BLk-94 is in the U genogroup, and 220-90 is in the $M$ genogroup (Emmenegger et al. 2000, Troyer et al. 2000, Kurath et al. 2003). The IHNV WRAC strain used as a source of the $\mathrm{G}$ gene in the vaccine $\mathrm{pIHNw}-\mathrm{G}$ is also in the $\mathrm{M}$ genogroup. Therefore, challenge of DNA vaccinated rainbow trout with IHNV isolate 220-90 represents an intragenogroup challenge in relation to the DNA vaccine, while the FR0031 and BLk-94 virus isolates used in the Chinook and sockeye challenges represent cross-genogroup challenges.
Mortalities were recorded daily for $30 \mathrm{~d}$ postchallenge and virus titers were determined in 13 to $24 \%$ of dead fish by plaque assay on confluent EPC cell monolayers (LaPatra et al. 1989). Mean viral titers were calculated after values determined for individual samples were transformed to log values. For all 5 vaccine trials, virus was confirmed in $100 \%$ of the mortalities tested, with mean titers of $2.1 \times 10^{5}$ to $1.6 \times 10^{7}$ plaque-forming units (pfu) $\mathrm{g}^{-1}$. Vaccine efficacy was determined by comparing the cumulative mortalities and survival times among vaccinated and control treatment groups. Survival curves were estimated using the Kaplan-Meier method, and a logrank test was used to compare the survival curves (SPSS 11.5 for Windows, SPSS). Samples with $\mathrm{p}<0.05$ were considered to show a significant difference. Relative percent survival (RPS) was calculated by: RPS = [1-(\% mortality of vaccinated fry $/ \%$ mortality of control fry) $\times 100$ (Croy \& Amend 1977). The \% mortality of control fry used to calculate RPS was the average cumulative mortalities of all pLuc, TE and unhandled controls.

Neutralizing antibody titers. Chinook and sockeye salmon fry in vaccine trials $1 \mathrm{C}$ and $2 \mathrm{~S}$ were euthanized in $500 \mu \mathrm{g} \mathrm{ml} \mathrm{m}^{-1}$ of MS-222 at 76 and $62 \mathrm{~d}$ postvaccination respectively, and blood was collected from the caudal vein after caudal transection. For each mock-challenged and challenged treatment group, 10 fish were bled and processed as 5 pools of 2 fish each to produce samples with sufficient volume for analysis. In treatments that had less than 10 survivors, all surviving fish were bled and processed as 2 fish pools. Neutralizing antibody titers were determined by complement dependent plaque neutralization assay using IHNV isolate 220-90 as previously described (LaPatra et al. 1993b). Data were analyzed using non-parametric Kruskal-Wallis with Dunn's post-hoc test. Samples with $\mathrm{p}<0.05$ were considered to show a significant difference. 


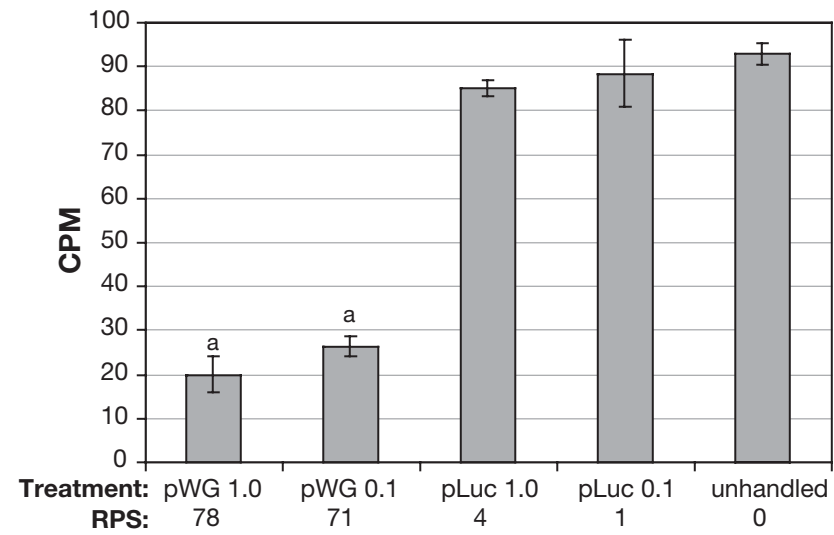

Fig. 1. Oncorhynchus tshawytscha. Cumulative \% mortality (CPM) and relative percent survival (RPS) of vaccinated Chinook fry after i.p. injection challenge with IHNV strain FR0031 45 d post-vaccination (trial 1C). a: pIHNw-G vaccinated groups that are significantly $(\mathrm{p}<0.05)$ different from their respective pLuc control group. Bars show average CPM in duplicate treatment groups and error bars indicate \pm SE of the means. The vaccine $\mathrm{pIHNw}-\mathrm{G}$ is abbreviated as pWG

\section{RESULTS}

\section{Efficacy of pIHNw-G DNA vaccine in Chinook fry}

Chinook salmon fry vaccinated with either 1.0 or $0.1 \mu \mathrm{g}$ of the pIHNw-G DNA vaccine and then challenged by i.p. injection of IHNV strain FR0031 exhibited significantly $(\mathrm{p}<0.05)$ less mortality than the control fry vaccinated with the pLuc vaccine or left unhandled (vaccine trial 1C, Fig. 1). Average cumulative percent mortality (CPM) in fish immunized with the pIHNw-G vaccine ranged from 20 to $26 \%$, whereas fish immunized with the control vaccine pLuc or left unhandled ranged from 85 to $93 \%$. The RPS observed in pIHNw-G vaccinated fish ranged from 71 to $78 \%$. No mortality occurred in any of the groups that were not exposed to virus.

\section{Efficacy of pIHNw-G DNA vaccine in sockeye fry}

Sockeye fry $(3.0 \mathrm{~g})$ vaccinated with 1.0 or $0.1 \mu \mathrm{g}$ of pIHNw-G and challenged by i.p. injection with IHNV isolate BLk-94 also showed significant protection ( $\mathrm{p}<$ 0.05) compared to control fish injected with the pLuc vaccine, TE or left unhandled (vaccine trial 2S, Fig. 2A). Cumulative percent mortality in fish groups vaccinated with the pIHNw-G vaccine ranged from 10 to $28 \%$, while the control fish ranged from 62 to $78 \%$. In this experiment there was also an apparent vaccine dose response in that the $1.0 \mu \mathrm{g}$ pIHNw-G vaccinated fish exhibited significantly $(p<0.05)$ less mortality than the $0.1 \mu \mathrm{g}$ pIHNw-G vaccinated fish. The RPS for the $1.0 \mu \mathrm{g}$ pIHNw-G vaccinated fish was $86 \%$, whereas sockeye salmon fry vaccinated with $0.1 \mu \mathrm{g}$ had an RPS of $61 \%$ (Fig. 2A). In control treatment groups not exposed to virus, mortality ranged from 4.5 to $32 \%$. The highest mortality occurred in the $0.1 \mu \mathrm{g}$ pIHNw-G vaccinated group, with the pLuc, TE and unhandled groups having 20,16, and $12 \%$ mortality respectively. The kinetics of this unexpected mortality began at $12 \mathrm{~d}$ post-challenge, substantially later than the onset of mortality in the virus challenged groups, which occurred $4 \mathrm{~d}$ post-challenge. All dead fish from each of the mock challenge groups were assayed for virus and no virus was detected. Although this unexplained mortality probably increased the mortality in all groups, the results clearly indicate that sockeye are significantly protected against IHNV when intramuscularly injected with the IHNV DNA vaccine.
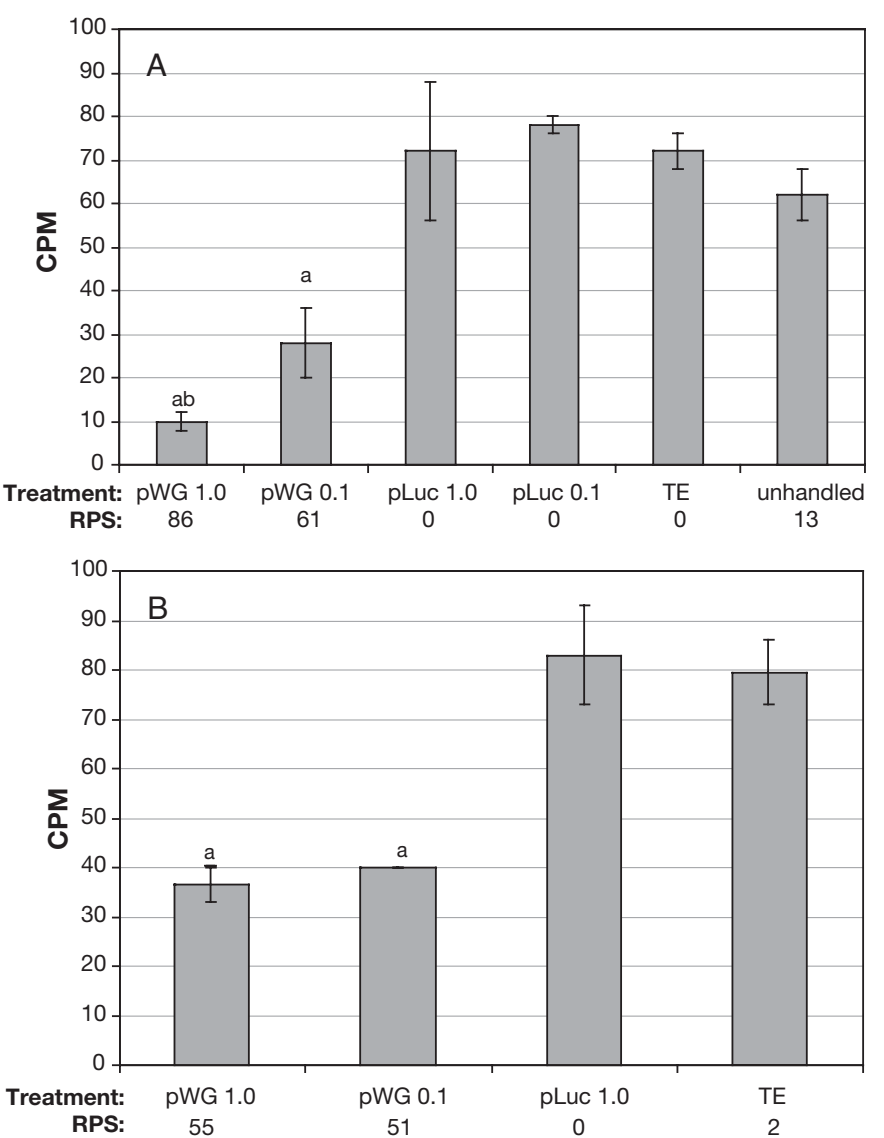

Fig. 2. Oncorhynchus nerka. Cumulative \% mortality (CPM) and relative percent survival (RPS) of vaccinated sockeye fry after (A) i.p. injection challenge of IHNV strain BLk-94 $35 \mathrm{~d}$ post-vaccination (trial 2S) or (B) IHNV immersion challenge 28 d post-vaccination (trial $3 \mathrm{~S}$ ). a: pIHNw-G vaccinated groups that are significantly $(\mathrm{p}<0.05)$ different from their respective pLuc control group; $b$ : significant difference between the 0.1 and $1.0 \mu \mathrm{g}$ pIHNw-G vaccinated groups. Absence of SE bars indicate that duplicate groups had identical CPM 


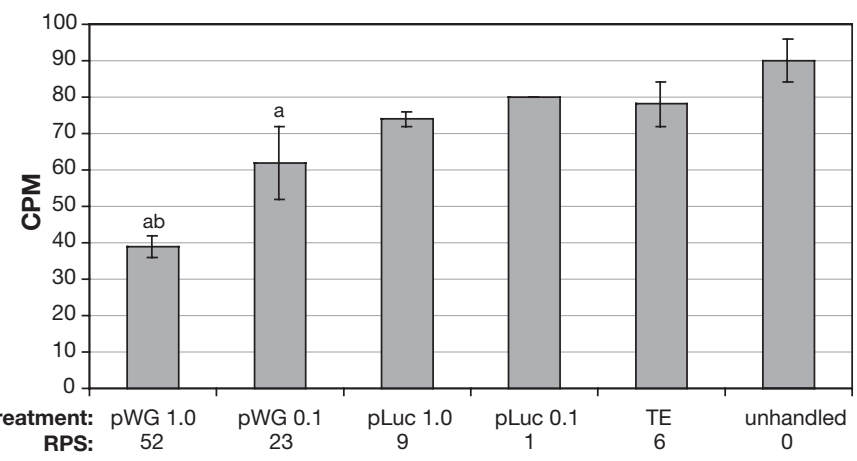

Fig. 3. Oncorhynchus nerka. Cumulative \% mortality (CPM) and relative percent survival (RPS) of vaccinated kokanee fry after immersion challenge with IHNV strain BLk-94 $28 \mathrm{~d}$ postvaccination (trial $4 \mathrm{~K}$ ). a: pIHNw-G vaccinated groups that are significantly $(\mathrm{p}<0.05)$ different from their respective pLuc control group; b: significant difference between the 0.1 and $1.0 \mu \mathrm{g}$ pIHNw-G vaccinated groups. Absence of SE bars indicate that duplicate groups had identical CPM

In a subsequent experiment, smaller sockeye fry $(1.0 \mathrm{~g})$ were vaccinated and challenged by waterborne immersion in IHNV strain BLk-94 at 28 d post vaccination (vaccine trial 3S). Similar to the first sockeye challenge described above, mortalities were significantly $(p<0.05)$ lower in the $\mathrm{pIHNw}-\mathrm{G}$ vaccine groups than in the pLuc and TE control groups (Fig. 2B). However, unlike the first sockeye challenge, no significant difference in mortality was observed between the different doses of pIHNw-G vaccine (Fig. 2B). The RPS of the 0.1 and $1.0 \mu \mathrm{g}$ pIHNw-G vaccinated groups was 51 and $55 \%$ respectively. No mortality occurred in any of the treatment groups not exposed to virus.

\section{Efficacy of pIHNw-G DNA vaccine in kokanee}

To test the efficacy of the IHNV DNA vaccine in a different stock of Oncorhynchus nerka, Lake Whatcom kokanee salmon fry (1.7 g) were vaccinated with either 1.0 or $0.1 \mu \mathrm{g}$ pIHNw-G and challenged by waterborne immersion in IHNV strain BLk-94 at 28 d post vaccination (vaccine trial $4 \mathrm{~K}$ ). Similar to the $O$. nerka challenges described previously, the pIHNw-G vaccinated groups showed significant protection against IHNV challenge compared with their respective pLuc control vaccinated fish. The average cumulative percent mortality in fish vaccinated with the IHNV DNA vaccine ranged from 39 to $62 \%$ while the pLuc, TE and unhandled fish ranged from 74 to $90 \%$ (Fig. 3). As observed in the $3.0 \mathrm{~g}$ sockeye fry challenged by i.p. injection, the $1.0 \mu \mathrm{g}$ pIHNw-G vaccinated fish exhibited significantly $(p<0.05)$ less mortality than the $0.1 \mu \mathrm{g}$ pIHNw-G vaccinated fish (Fig. 3). No mortality occurred in any of the treatment groups not exposed to virus.

\section{Efficacy of pIHNw-G DNA vaccine in rainbow trout at $10^{\circ} \mathrm{C}$}

To date, all published pIHNw-G vaccine efficacy studies conducted in rainbow trout have been performed at temperatures ranging from 12 to $15^{\circ} \mathrm{C}$, which is higher than the $10^{\circ} \mathrm{C}$ temperature used in the vaccine efficacy studies described in this report. Therefore, in order to compare pIHNw-G vaccine efficacy in rainbow trout to that in Chinook and sockeye at the same temperature, rainbow trout (mean weight, $3.2 \mathrm{~g}$ ) held at $10^{\circ} \mathrm{C}$ were vaccinated with either 1.0 or $0.1 \mu \mathrm{g}$ pIHNw-G and challenged by waterborne immersion with IHNV strain 220-90 at 28 d postvaccination. The pIHNw-G vaccinated fish showed no mortality, while the average CPM of the pLuc, TE, and unhandled fish groups ranged from 40 to $58 \%$ (Fig. 4). Both doses of pIHNw-G provided $100 \%$ protection against viral challenge, illustrating the effectiveness of the IHNV DNA vaccine in rainbow trout at $10^{\circ} \mathrm{C}$. No mortality occurred in any of the treatment groups not exposed to virus.

\section{IHNV neutralizing antibody titers in vaccinated Chinook and sockeye salmon fry}

Specific IHNV neutralizing antibodies (NAbs) were quantified for Chinook and sockeye fry from vaccine trials $1 \mathrm{C}$ and $2 \mathrm{~S}$. Sera were collected from both viral challenged and mock challenged groups. Titers in fish from the mock challenged groups provide a measure of the neutralizing antibody response to the vaccine itself. Mock challenged Chinook fry vaccinated with

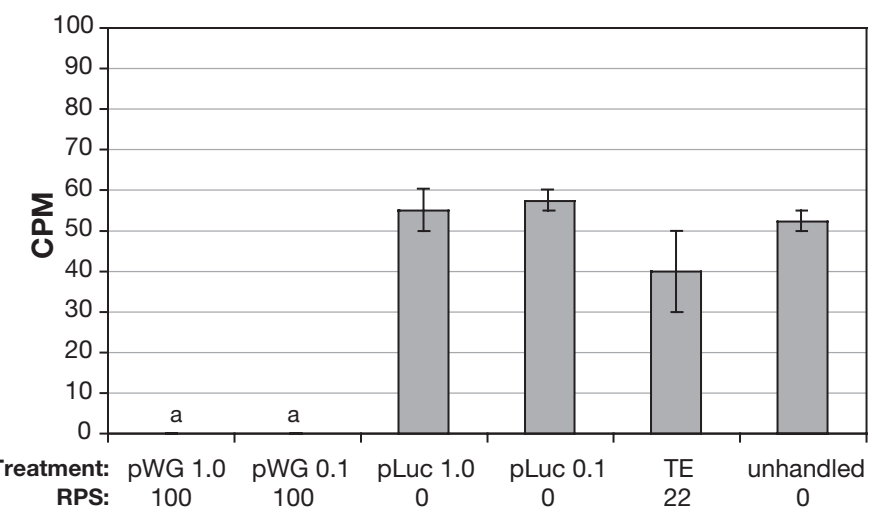

Fig. 4. Oncorhynchus mykiss. Cumulative \% mortality (CPM) and relative percent survival (RPS) of vaccinated rainbow trout at $10^{\circ} \mathrm{C}$ after immersion challenge with IHNV strain 220-90 (trial 5R). a: pIHNw-G vaccinated groups that are significantly $(p<0.05)$ different from their respective pLuc control group 
pIHNw-G had high seroprevalence while sera pools from the mock challenged pLuc or TE control treatment groups had no detectable NAb titers, with the exception of a single pool in the $0.1 \mu \mathrm{g}$ pLuc group that showed a low titer (Table 2). Likewise, among the sera collected from the mock challenged sockeye fry, fish vaccinated with either 1.0 or $0.1 \mu \mathrm{g}$ pIHNw-G had a seroprevalence of $100 \%(5 / 5)$, while the pLuc, TE or unhandled treatments had no virus-neutralizing antibody titers (Table 2).

Table 2. Oncorhynchus tshawytscha and O. nerka. IHNV neutralizing antibody titers at 76 and $62 \mathrm{~d}$ post-vaccination (30 d post-challenge) respectively. Each sera pool consisted of 2 fish. Titers are reported as the reciprocal of the highest dilution that resulted in a $50 \%$ reduction in the average number of plaques detected in the negative controls. Parentheses indicate number of sera pools with the titer specified

\begin{tabular}{|c|c|c|}
\hline Treatment & $\begin{array}{l}\text { No. positive sera/ } \\
\text { total no. sera pools }\end{array}$ & $\begin{array}{c}\text { Neutralizing } \\
\text { antibody titers }\end{array}$ \\
\hline \multicolumn{3}{|c|}{ Chinook from Vaccine Trial 1C } \\
\hline \multicolumn{3}{|c|}{ Mock challenge } \\
\hline $0.1 \mu \mathrm{g}$ & $4 / 5$ & $<20,(2) 20,(2) 40$ \\
\hline $1.0 \mu \mathrm{g}$ & $5 / 5$ & $(2) 80,(3) \geq 160^{\mathrm{a}}$ \\
\hline \multicolumn{3}{|l|}{ pLuc: } \\
\hline $0.1 \mu \mathrm{g}$ & $1 / 5$ & $(4)<20,20$ \\
\hline $1.0 \mu \mathrm{g}$ & $0 / 5$ & $(5)<20$ \\
\hline $\mathrm{TE}$ & $0 / 5$ & $(5)<20$ \\
\hline \multicolumn{3}{|l|}{ Challenge } \\
\hline $0.1 \mu \mathrm{g}$ & $5 / 5$ & $(5) \geq 160^{a}$ \\
\hline $1.0 \mu \mathrm{g}$ & $5 / 5$ & $(5) \geq 160^{a}$ \\
\hline \multicolumn{3}{|l|}{ pLuc: } \\
\hline $0.1 \mu \mathrm{g}$ & $1 / 3$ & $(2)<20,20$ \\
\hline $1.0 \mu \mathrm{g}$ & $1 / 3$ & $(2)<20,80$ \\
\hline TE & $1 / 1$ & 40 \\
\hline \multicolumn{3}{|c|}{ Sockeye from Vaccine Trial $2 S$} \\
\hline \multicolumn{3}{|c|}{ Mock challenge } \\
\hline $0.1 \mu \mathrm{g}$ & $5 / 5$ & $20,40,(3) \geq 160^{\mathrm{a}}$ \\
\hline $1.0 \mu \mathrm{g}$ & $5 / 5$ & $40,(2) 80,(2) \geq 160^{\mathrm{a}}$ \\
\hline \multicolumn{3}{|l|}{ pLuc: } \\
\hline $0.1 \mu \mathrm{g}$ & $0 / 5$ & $(5)<20$ \\
\hline $1.0 \mu \mathrm{g}$ & $0 / 5$ & $(5)<20$ \\
\hline TE & $0 / 5$ & $(5)<20$ \\
\hline Unhandled & $0 / 5$ & $(5)<20$ \\
\hline \multicolumn{3}{|l|}{$\begin{array}{l}\text { Challenge } \\
\text { pIHNw-G: }\end{array}$} \\
\hline $0.1 \mu \mathrm{g}$ & $5 / 5$ & $(5) \geq 160$ \\
\hline $1.0 \mu \mathrm{g}$ & $5 / 5$ & $(5) \geq 160$ \\
\hline \multicolumn{3}{|l|}{ pLuc: } \\
\hline $0.1 \mu \mathrm{g}$ & $5 / 5$ & $20,(2) 40,80, \geq 160$ \\
\hline $1.0 \mu \mathrm{g}$ & $5 / 5$ & $40,80,(3) \geq 160$ \\
\hline TE & $3 / 3$ & $20,40,80$ \\
\hline Unhandled & $5 / 5$ & $20,(3) 80, \geq 160$ \\
\hline
\end{tabular}

Neutralizing antibody titers were also determined from all treatment groups of Chinook and sockeye fry that survived IHNV challenge. Among Chinook challenge survivors, the highest neutralizing antibody titers occurred in the pIHNw-G vaccinated groups. All sera from pIHNw-G vaccinated Chinook had titers of 160 or higher while less than half of the control treatment sera had detectable titers. Similarly, among sockeye challenge survivors, the highest neutralizing antibody titers occurred in the pIHNw-G vaccinated group, which all had titers of $\geq 160$ (Table 2). Although all sockeye sera from the pLuc, TE and unhandled control treatments had detectable titers, they were considerably lower than the pIHNw-G groups. There was no difference in neutralizing antibody titers observed between the different doses of the pIHNw-G DNA vaccine for either Chinook or sockeye sera.

\section{DISCUSSION}

A number of factors are important to consider in the development of an ideal viral vaccine. The primary one, of course, is that the vaccine must provide adequate protection against the disease. However, also important is that the protection provided by the vaccine is against multiple variants of the pathogen, is long lasting and is elicited by a small vaccine dose. Past experiments investigating IHNV DNA vaccines in rainbow trout and Atlantic salmon have demonstrated that such attributes are met, suggesting that DNA vaccines are effective tools for prophylaxis of IHNV. These beneficial attributes prompted the present study aimed at determining the efficacy of the pIHNw-G vaccine in 2 other highly susceptible salmonid species: Chinook Oncorhynchus tshawytscha, and sockeye/kokanee (the anadromous and landlocked forms of O. nerka) salmon.

The studies reported herein demonstrated that Chinook and sockeye fry vaccinated with the IHNV DNA vaccine were protected experimentally against lethal concentrations of IHNV much higher than fish would naturally encounter. A single $0.1 \mu \mathrm{g}$ dose of the pIHNw-G vaccine provided significant protection in these salmonid species. This result correlates with observations in rainbow trout (Corbeil et al. 2000b). It is interesting to note that, although vaccinated Chinook, sockeye and kokanee salmon exhibited protection against IHNV challenge, the level of protection is not as high as that reported for pIHNw-G vaccinated rainbow trout. The combined results of 8 different vaccine trials from previously published reports and trial 5R here (Table 3, lines 1-9), revealed an average RPS of $89.4 \%$ for 1 to $3 \mathrm{~g}$ rainbow trout vaccinated with $0.1 \mu \mathrm{g}$ pIHNw-G and challenged with an intra- 
Table 3. Oncorhynchus spp. Summary of intra- and cross-genogroup DNA vaccine trials with $0.1 \mu \mathrm{g}$ or $1.0 \mu \mathrm{g}$ doses of pIHNw-G vaccine (M genogroup) in 1 to $3 \mathrm{~g}$ fry. Rbt: rainbow trout; Soc: sockeye; Kok: kokanee; Chin: Chinook; RPS: relative percent survival

\begin{tabular}{|c|c|c|c|c|c|c|c|c|}
\hline $\operatorname{Line}^{a}$ & $\begin{array}{c}\text { pIHNw-G } \\
\text { dose }(\mu \mathrm{g})\end{array}$ & $\begin{array}{c}\text { Challenge } \\
\text { genogroup, } \\
\text { strain }\end{array}$ & $\begin{array}{l}\text { Challenge } \\
\text { route, } \\
\text { dose }\end{array}$ & $\begin{array}{c}\text { Host } \\
\text { species, } \\
\text { size }(g)\end{array}$ & $\begin{array}{l}\text { Challenge } \\
\text { time (dpv) }\end{array}$ & $\begin{array}{c}\text { CPM vacc./ } \\
\text { CPM } \\
\text { controls }^{\mathrm{b}}\end{array}$ & $\mathrm{RPS}^{\mathrm{c}}$ & Source $^{\mathrm{d}}$ \\
\hline \multicolumn{9}{|c|}{ Intragenogroup challenges } \\
\hline 1 & 0.1 & M, WRAC & imm. $1.0 \times 10^{1}$ & Rbt, 2.5 & 42 & $0 / 23-28$ & $(100)$ & 2 \\
\hline 2 & 0.1 & M, WRAC & imm. $1.0 \times 10^{2}$ & Rbt, 2.5 & 42 & $2 / 11-23$ & $(91)$ & 2 \\
\hline 3 & 0.1 & M, WRAC & imm. $1.0 \times 10^{3}$ & Rbt, 2.5 & 42 & $6 / 60$ & 90 & 2 \\
\hline 4 & 0.1 & M, WRAC & imm. $1.0 \times 10^{3}$ & Rbt, 2.3 & 42 & $8 / 80$ & 90 & 2 \\
\hline 5 & 0.1 & M, WRAC & imm. $1.0 \times 10^{4}$ & Rbt, 2.5 & 42 & $2 / 30-48$ & (96) & 2 \\
\hline 6 & 0.1 & M, 220-90 & imm. $2.8 \times 10^{4}$ & Rbt, 1.8 & 29 & $0 / 80$ & 100 & 3 \\
\hline 7 & 0.1 & M, 220-90 & imm. $1.0 \times 10^{5}$ & Rbt, 3.2 & 28 & $0 / 51$ & $(100)$ & 5 \\
\hline 8 & 0.1 & M, 220-90 & imm. $1.0 \times 10^{6}$ & $\mathrm{Rbt}, 2.3$ & 42 & $42 / 96$ & 56 & 2 \\
\hline 9 & 0.1 & M, 32-87 & imm. $1.0 \times 10^{6}$ & $\mathrm{Rbt}, 2.3$ & 42 & $12 / 68$ & 82 & 2 \\
\hline 10 & 1.0 & M, WRAC & imm. $1.0 \times 10^{1}$ & Rbt, 2.5 & 42 & $0 / 23-28$ & $(100)$ & 2 \\
\hline 11 & 1.0 & M, WRAC & imm. $1.0 \times 10^{2}$ & Rbt, 2.5 & 42 & $0 / 11-23$ & (100) & 2 \\
\hline 12 & 1.0 & M, WRAC & imm. $1.0 \times 10^{4}$ & Rbt, 2.5 & 42 & $0 / 30-48$ & (100) & 2 \\
\hline 13 & 1.0 & M, 220-90 & imm. $1.0 \times 10^{4}$ & Rbt, 2.0 & 21 & $2 / 40-62$ & 95 & 4 \\
\hline 14 & 1.0 & M, 220-90 & imm. $1.0 \times 10^{4}$ & Rbt, 2.0 & 28 & $1 / 68-82$ & 98 & 4 \\
\hline 15 & 1.0 & M, 220-90 & imm. $1.0 \times 10^{4}$ & Rbt, 2.0 & 28 & $17 / 68-82$ & 77 & 4 \\
\hline 16 & 1.0 & M, 220-90 & imm. $1.0 \times 10^{5}$ & Rbt, 2.0 & 28 & $2 / 60$ & 97 & 1 \\
\hline 17 & 1.0 & M, 220-90 & imm. $1.0 \times 10^{5}$ & Rbt, 3.2 & 28 & $0 / 51$ & $(100)$ & 5 \\
\hline \multicolumn{9}{|c|}{ Cross-genogroup challenges } \\
\hline 18 & 0.1 & $\mathrm{U}, \mathrm{AK} 14$ & imm. $1.0 \times 10^{5}$ & $\mathrm{Rbt}, 2.3$ & 42 & $6 / 24$ & (75) & 2 \\
\hline 19 & 0.1 & $\mathrm{U}, \mathrm{RB} 1$ & imm. $1.0 \times 10^{7}$ & Rbt, 2.3 & 42 & $10 / 36$ & (72) & 2 \\
\hline 20 & 0.1 & U,Shizuoka & imm. $1.0 \times 10^{5}$ & Rbt, 2.3 & 42 & $22 / 78$ & 72 & 2 \\
\hline 21 & 0.1 & L, Col-85 & imm. $1.0 \times 10^{7}$ & Rbt, 2.3 & 42 & $4 / 12$ & (67) & 2 \\
\hline 22 & 0.1 & U, BLk-94 & i.p., $1.7 \times 10^{7}$ & Soc, 3.0 & 35 & $28 / 62-78$ & 61 & 5 \\
\hline 23 & 0.1 & U, BLk-94 & imm. $2 \times 10^{5}$ & Soc, 0.7 & 28 & $40 / 80-83$ & 51 & 5 \\
\hline 24 & 0.1 & U, BLk-94 & imm. $2 \times 10^{5}$ & Kok, 1.7 & 28 & $62 / 74-90$ & 23 & 5 \\
\hline 25 & 0.1 & L, FR0031 & i.p., $3.4 \times 10^{6}$ & Chin, 3.0 & 45 & $26 / 85-93$ & 71 & 5 \\
\hline 26 & 1.0 & U, BLk-94 & i.p., $1.7 \times 10^{7}$ & Soc, 3.0 & 35 & $10 / 62-78$ & 86 & 5 \\
\hline 27 & 1.0 & U, BLk-94 & imm. $2 \times 10^{5}$ & Soc, 0.7 & 28 & $37 / 80-83$ & 55 & 5 \\
\hline 28 & 1.0 & U, BLk-94 & imm. $2 \times 10^{5}$ & Kok, 1.7 & 28 & $39 / 74-90$ & 52 & 5 \\
\hline 29 & 1.0 & L, FR0031 & i.p., $3.4 \times 10^{6}$ & Chin, 3.0 & 45 & $20 / 85-93$ & 78 & 5 \\
\hline
\end{tabular}

genogroup IHNV. This is considerably higher then the $51.5 \%$ average RPS obtained from the IHNV challenge experiments of $0.1 \mu \mathrm{g}$ pIHNw-G vaccinated Chinook and sockeye described here (Table 3, lines 22-25). This phenomenon also occurred at a higher vaccine dose. IHNV challenge of $1.0 \mu \mathrm{g}$ pIHNw-G vaccinated rainbow trout (Table 3, lines 10-17) revealed an average RPS of $97 \%$ compared to an average RPS of $68 \%$ for Chinook and sockeye salmon also vaccinated at the same dose (Table 3, lines 26-29).

There are several factors that may account for this reduced efficacy of the IHNV DNA vaccine in Chinook and sockeye salmon. These include: experimental temperature differences, the inherent ability of different species to respond to the vaccine and/or different
IHNV strains, genetic differences between vaccine and challenge viruses, or differences in severity of virus challenge. The effects of these different factors on vaccine efficacy are discussed below.

Because fish are poikilothermic (cold-blooded), physiological processes including immune stimulation due to vaccination or viral infection, are greatly affected by the environmental temperature (Vallejo et al. 1992). For instance, the protective responses afforded by fish rhabdovirus DNA vaccines, which include early non-specific antiviral mechanisms followed by the more slowly activated specific protection (Kim et al. 2000, LaPatra et al. 2001, Lorenzen et al. 2002, Sommerset et al. 2003), may differ depending on the experimental temperature of vaccinated fish. In 
this study, vaccination trials in Chinook and sockeye/ kokanee salmon were conducted at $10^{\circ} \mathrm{C}$, while previous vaccinations of rainbow trout were conducted at either 12 or $15^{\circ} \mathrm{C}$ (Corbeil et al. 1999, 2000a,b). To address this difference in the experimental design we administered pIHNw-G to size-matched rainbow trout at $10^{\circ} \mathrm{C}$ and compared the vaccine efficacy to that obtained in Chinook and sockeye/kokanee salmon. The rainbow trout vaccinated at $10^{\circ} \mathrm{C}$ still exhibited a higher RPS, suggesting that temperature alone cannot explain the vaccine efficacy differences between these species.

The different vaccine efficacy observed between salmon and trout may be due in part to inherent differences between species and between stocks of a particular host species. In the studies described here we have not assessed whether the protection observed was due to a prolonged early non-specific immunity or to the slower adaptive immune response. The results obtained could be due to host-specific differences in the strength of either the innate or adaptive responses, or to a difference in kinetics of shifting from the innate to adaptive responses. For instance, it is possible that the vaccinated salmon were unable to mount an adaptive response as quickly as the vaccinated rainbow trout at $10^{\circ} \mathrm{C}$ so that at time of challenge the rainbow trout would have a greater level of protection. It is well documented that stocks or races of fish may differ in resistance to viral and bacterial diseases due to genetic differences (Gjedrem \& Aulstad 1974, Hines et al. 1974, Plumb et al. 1975, Amend \& Nelson 1977). Thus it is conceivable that vaccine efficacy differences may also be due to inherent genetic differences between different species and/or stocks. In this study vaccine efficacy was tested in 2 different stocks of Oncorhynchus nerka (vaccine trials $3 \mathrm{~S}$ and $4 \mathrm{~K}$ ). Different levels of protection between the 2 stocks were only observed in fish vaccinated with a $0.1 \mu \mathrm{g}$ dose of $\mathrm{pIHNw}-\mathrm{G}$, while fish vaccinated with $1.0 \mu \mathrm{g}$ dose of pIHNw-G were equally well protected against a similar IHNV immersion challenge. This observation of subtle differences in vaccine efficacy between stocks suggests that such differences will exist or may even be accentuated between species.

Another factor that may account for the difference in vaccine efficacy between the salmon and trout species is the use of different IHNV challenge strains. The viral challenge strains used in the Chinook and sockeye/ kokanee vaccine trials were selected based on their ability to cause high mortality in these host species, but genetically they are less similar to the vaccine strain than the challenge virus used in the rainbow trout experiment. Based on the IHNV genetic typing system defined by Kurath et al. (2003), the pIHNw-G vaccine carries the G gene of a viral strain (WRAC) that is in the $\mathrm{M}$ genogroup, while the challenge strains used in the Chinook and sockeye/kokanee challenges are in the $\mathrm{L}$ and $\mathrm{U}$ genogroups, respectively. Therefore, these species experienced a cross-genogroup challenge, while rainbow trout were challenged with an intragenogroup virus belonging to the same genogroup (M) as the vaccine strain. Both the intragenogroup and cross-genogroup challenges represented heterologous challenges (i.e. challenge with an IHNV strain different from the WRAC strain represented by the pIHNw$G$ vaccine). However, the intragenogroup challenge in rainbow trout was genetically more similar to the DNA vaccine than the cross-genogroup challenges in Chinook and sockeye. Presumably, the vaccine will best protect against an infectious agent that most closely resembles the vaccine antigen, in other words an intragenogroup challenge. This hypothesis is supported by the results of numerous pIHNw-G vaccine trials compiled in Table 3 that indicate higher vaccine efficacy against intragenogroup challenges compared to cross-genogroup challenges.

An exception to this general observation is the RPS of 56.2 reported for an intragenogroup pIHNw-G vaccine trial in rainbow trout (Corbeil et al 2000b) (Table 3, line 8). However this lower level of efficacy may be attributed to the extremely severe challenge conditions, since a subsequent experiment by the same researchers using a less severe virus challenge resulted in a $100 \%$ RPS (Corbeil et al. 2000b) (Table 3, compare lines 6 and 8). This suggests that the severity of the challenge can overwhelm protection afforded by the DNA vaccine, reducing the RPS. The effect of challenge severity on vaccine efficacy has been noted elsewhere (Engelking \& Leong 1989a,b).

It is interesting that in some of the Chinook and sockeye/kokanee salmon challenges an increased vaccine dose correlated with an increase in protection. This dose-dependent effect on protection suggests that lower vaccine efficacy may be overcome by increasing vaccine dose. This is supported by reports by Anderson et al. (1996) and Kim et al. (2000) in which $10 \mu \mathrm{g}$ doses (10 to 100-fold increase over the doses used in the present study) of an IHNV DNA vaccine in rainbow trout provided an RPS of $75-93 \%$ for cross-genogroup challenges (U genogroup vaccine and $\mathrm{M}$ genogroup challenge virus).

DNA vaccinations of Chinook and sockeye induced IHNV neutralizing antibodies, as was noted in vaccinations of rainbow trout (Corbeil et al. 1999, 2000b, LaPatra et al. 2000) and Atlantic salmon (Traxler et al. 1999). In this report, neutralizing antibody titers were detected in both Chinook and sockeye that had been vaccinated with either 0.1 or $1.0 \mu \mathrm{g}$ doses of the DNA vaccine and then mock challenged. In the mock chal- 
lenged pIHNw-G vaccinated Chinook it appears that the higher vaccine dose elicited higher neutralizing antibody titers. This dose-dependent effect was not evident for the vaccinated sockeye. Chinook and sockeye challenge survivors from either the 0.1 or $1.0 \mu \mathrm{g}$ pIHNw-G vaccinated groups showed equally high neutralizing antibody titers of 160 or higher. These antibody titers from the pIHNw-G vaccinated challenge survivors were considerably higher than the control vaccinated challenged fish, suggesting that the IHNV DNA vaccine not only induces IHNV neutralizing antibodies but also enhances seroconversion such that the DNA vaccine primed the antibody response to the challenge virus. Similar results have been observed in pIHNw-G vaccinated rainbow trout (LaPatra et al. 2000) and in other DNA vaccine model systems (Bahloul et al. 1998). It is interesting to note that although neutralizing antibody titers were equal between the sockeye challenge survivors from both the 0.1 and the $1.0 \mu \mathrm{g}$ pIHNw-G vaccinated groups, a significantly higher protection was observed in the $1.0 \mu \mathrm{g}$ pIHNw-G vaccinated group compared to the $0.1 \mu \mathrm{g}$ group. This observation may have been influenced by how long after vaccination serum was obtained for antibody analysis. It is possible that different antibody titers were present between vaccine doses at the time of challenge (35 d post-vaccination); however, they were not reflected when antibody titers were determined at $62 \mathrm{~d}$ post-vaccination. It may also be possible that the $1.0 \mu \mathrm{g}$ dose of the IHNV DNA vaccine stimulates factors other than neutralizing antibodies that may enhance protection against viral challenge.

In summary, Chinook and sockeye salmon can be included along with rainbow trout and Atlantic salmon as species that elicit a protective immune response following injection with an IHNV DNA vaccine. Vaccinated Chinook and sockeye salmon fry were protected against cross-genogroup challenges with a single low vaccine dose; however results presented here indicate that RPS values are lower, and optimization may be necessary to achieve maximum efficacy. Further research is needed to determine if higher vaccine doses may provide greater protection in these species and if the development of a multivalent IHNV DNA vaccine is necessary for the enhancement of the protection provided by this potent vaccine.

Acknowledgements. We thank Ray Brunson, Jed Varney, and Doug Huddle for providing the fish and Ronald Hedrick and Joan Thomas for providing the viral isolates. We also thank Bill Shewmaker for determining the neutralizing antibody titers, Maureen Purcell and Jeff Duda for their assistance on statistical analyses and Jim Winton and Caroline Josefsson for reviewing this manuscript. This work was supported by the U.S.G.S Western Fisheries Research Center.

\section{LITERATURE CITED}

Amend DF, Nelson JR (1977) Variation in the susceptibility of sockeye salmon Oncorhynchus nerka to infectious hematopoietic necrosis virus. J Fish Biol 11:567-573

Amend DF, Yasutake WT, Mead RW (1969) A hematopoietic virus disease of rainbow trout and sockeye salmon. Trans Am Fish Soc 98:796-804

Anderson ED, Mourich DV, Fahrenkrug SC, LaPatra S, Shepherd J, Leong JC (1996) Genetic immunization of rainbow trout (Oncorhynchus mykiss) against infectious hematopoietic necrosis virus. Mol Mar Biol Biotechnol 5: $114-122$

Anonymous (2002) Diseased sockeye euthanized at Bonneville Hatchery. Oregon Dept of Fish and Wildlife News Release June 4 ODFW, Portland, OR

Bahloul C, Jacob Y, Tordo N, Perrin P (1998) DNA-based immunization for exploring the enlargement of immunological cross-reactivity against the lyssaviruses. Vaccine 16:417-425

Corbeil S, LaPatra SE, Anderson ED, Jones J, Vincent B, Hsu YL, Kurath G (1999) Evaluation of the protective immunogenicity of the N, P, M, NV and G proteins of infectious hematopoietic necrosis virus in rainbow trout Oncorhynchus mykiss using DNA vaccines. Dis Aquat Org 39: 29-36

Corbeil S, Kurath G, LaPatra SE (2000a) Fish DNA vaccine against infectious hematopoietic necrosis virus: efficacy of various routes of immunization. Fish Shellfish Immunol 10: 711-723

Corbeil S, LaPatra SE, Anderson ED, Kurath G (2000b) Nanogram quantities of a DNA vaccine protect rainbow trout fry against heterologous strains of infectious hematopoietic necrosis virus. Vaccine 18:2817-2824

Croy TR, Amend DF (1977) Immunization of sockeye salmon (Oncorhynchus nerka) against vibriosis using the hyperosmotic infiltration technique. Aquaculture 12:317-325

Emmenegger EJ, Meyers TR, Burton TO, Kurath G (2000) Genetic diversity and epidemiology of infectious hematopoietic necrosis virus in Alaska. Dis Aquat Org 40: 163-176

Engelking HM, Leong JC (1989a) Glycoprotein from infectious hematopoietic necrosis virus (IHNV) induces protective immunity against five IHNV types. J Aquat Anim Health 1:291-300

Engelking HM, Leong JC (1989b) The glycoprotein of infectious hematopoietic necrosis virus elicits neutralizing antibody and protective responses. Virus Res 13:213-230

Fijan N, Sulimanovic D, Bearzotti M, Muzinic D, Zwillenberg LO, Chilmonczyk S, Vautherot JF, de Kinkelin P (1983) Some properties of the Epithelioma papulosum cyprini (EPC) cell line from carp Cyprinus carpio. Ann Virol 134: 207-220

Gjedrem T, Aulstad D (1974) Selection experiments with salmon. 1. Differences in resistance to vibrio disease of salmon parr (Salmo Salar). Aquaculture 3:51-59

Groberg WJ, Onjukka ST, Brown KA, Holt RA (1999) A report of infectious disease epidemiology among spring Chinook salmon at Lookingglass hatchery. Oregon Department of Fish and Wildlife, La Grande, OR

Hines RS, Wohlfarth GW, Moav R, Hulata G (1974) Genetic differences in susceptibility to two diseases among strains of the common carp. Aquaculture 3:187-197

Kim CH, Johnson MC, Drennan JD, Simon BE, Thomann E, Leong JC (2000) DNA vaccines encoding viral glycoproteins induce nonspecific immunity and Mx protein synthesis in fish. J Virol 74:7048-7054 
Kurath G, Garver KA, Troyer RM, Emmenegger EJ, EinerJensen K, Anderson ED (2003) Phylogeography of infectious hematopoietic necrosis virus in North America. J Gen Virol 84:803-814

LaPatra SE (1998) Factors affecting pathogenicity of infectious hematopoietic necrosis virus (IHNV) for salmonid fish. J Aquat Anim Health 10:121-131

LaPatra SE, Roberti KA, Rohovec JS, Fryer JL (1989) Fluorescent antibody test for the rapid diagnosis of infectious hematopoietic necrosis. J Aquat Anim Health 1:29-36

LaPatra SE, Groberg WJ, Rohovec JS, Fryer JL (1990a) Sizerelated susceptibility of salmonids to two strains of infectious hematopoietic necrosis virus. Trans Am Fish Soc 119: 25-30

LaPatra SE, Groff JM, Fryer JL, Hedrick RP (1990b) Comparative pathogenesis of three strains of infectious hematopoietic necrosis virus in rainbow trout Oncorhynchus mykiss. Dis Aquat Org 8:105-112

LaPatra SE, Lauda KA, Morton AW (1991) Antigenic and virulence comparisons of eight isolates of infectious hematopoietic necrosis virus from the Hagerman Valley, Idaho, USA. In: Proc 2nd Int Symp on Viruses of Lower Vertebrates. Oregon State University, Corvallis, OR, p 125-132

LaPatra SE, Fryer JL, Rohovec JS (1993a) Virulence comparison of different electropherotypes of infectious hematopoietic necrosis virus. Dis Aquat Org 16:115-120

LaPatra SE, Turner T, Lauda KA, Jones GR, Walker S (1993b) Characterization of the humoral response of rainbow trout to infectious hematopoietic necrosis virus. J Aquat Anim Health 5:165-171

LaPatra SE, Lauda KA, Jones GR (1994) Antigenic variants of infectious hematopoietic necrosis virus and implications for vaccine development. Dis Aquat Org 20:119-126

LaPatra SE, Corbeil S, Jones GR, Shewmaker WD, Kurath G (2000) The dose-dependent effect on protection and humoral response to a DNA vaccine against infectious hematopoietic necrosis (IHN) virus in subyearling rainbow trout. J Aquat Anim Health 12:181-188

LaPatra SE, Corbeil S, Jones GR, Shewmaker WD, Lorenzen N, Anderson ED, Kurath G (2001) Protection of rainbow trout against infectious hematopoietic necrosis virus four days after specific or semi-specific DNA vaccination. Vaccine 19:4011-4019

Lorenzen N, Lorenzen E, Einer-Jensen K, LaPatra SE (2002) Immunity induced shortly after DNA vaccination of rainbow trout against rhabdoviruses protects against heterologous virus but not against bacterial pathogens. Dev Comp Immunol 26:173-179

Meyers TR, Korn D, Burton TM, Glass K and 6 others (2003) Infectious hematopoietic necrosis virus (IHNV) in Alaskan

Editorial responsibility: Carey Cunningham, Aberdeen, UK sockeye salmon culture from 1973 to 2000: annual virus prevalences and titers in broodstocks compared with juvenile losses. J Aquat Anim Health 15:21-30

Morzunov SP, Winton JR, Nichol ST (1995) The complete genome structure and phylogenetic relationship of infectious hematopoietic necrosis virus. Virus Res 38:175-192

Mulcahy D, Pascho RJ, Jenes CK (1983) Detection of infectious hematopoietic necrosis virus in river water and demonstration of waterborne transmission. J Fish Dis 6: 321-330

Mulcahy D, Wood J (1986) A natural epizootic of infectious haematopoietic necrosis in imported Atlantic salmon, Salmo salar, reared in the enzootic region. Fish Dis 9: 173-175

Plumb JA, Green OL, Smitherman RO, Pardue GB (1975) Channel catfish virus experiments with different strains of channel catfish. Trans Am Fish Soc 104:140-143

Ross AJ, Pelnar J, Rucker RR (1960) A virus-like disease of Chinook salmon. Trans Am Fish Soc 89:160-163

Rucker RR, Whipple WJ, Parvin JR, Evans CA (1953) A contagious disease of sockeye salmon possibly of virus origin. US Fish Wild Serv Fish Bull 54:35-46

Saporito-Irwin SM, Geist RT, Gutmann DH (1997) Ammonium acetate protocol for the preparation of plasmid DNA suitable for mammalian cell transfections. Biotechniques 23:424-427.

Sommerset I, Lorenzen E, Lorenzen N, Bleie H, Nerland AH (2003) A DNA vaccine directed against a rainbow trout rhabdovirus induces early protection against a nodavirus challenge in turbot. Vaccine 21:4661-4667

Traxler GS, Anderson E, LaPatra SE, Richard J, Shewmaker B, Kurath G (1999) Naked DNA vaccination of Atlantic salmon Salmo salar against IHNV. Dis Aquat Org 38: 183-190

Troyer RM, LaPatra SE, Kurath G (2000) Genetic analyses reveal unusually high diversity of infectious haematopoietic necrosis virus in rainbow trout aquaculture. J Gen Virol 81:2823-2832

Vallejo AN, Miller NW, Clem LW (1992) Cellular pathway(s) of antigen processing in fish APC: effect of varying in vitro temperatures on antigen catabolism. Dev Comp Immunol 16:367-381

Watson SW, Guenther RW, Rucker RR (1954) A virus disease of sockeye salmon: interim report. US Fish Wildl Serv Spec Sci Rep Fish 138:1-36

Wingfield WH, Chan LD (1970) Studies on the Sacramento River chinook disease and its causative agent. In: Snieszko SF (ed) A symposium on diseases of fish and shellfish. American Fisheries Society, Washington, DC, p $307-318$

Submitted: April 22, 2004; Accepted: September 30, 2004 Proofs received from author(s): March 2, 2005 